the role of sexual selection rather than natural selection in their genesis. The public controversy she chooses to highlight here is the one between T. H. Huxley and the Christians, but that was not about race, and she might have done better to consider the debates, in which the Darwinians were embroiled, between the rival Anthropological and Ethnological Societies, which were divided not only on the scientific issues but also by their views on slavery. This would have brought out the fact that Darwin and Huxley, at any rate, were never naive about the political implications of their theories.

The story then shifts to Germany, where the protagonists were Ernst Haeckel, a Darwinian but also a romantic nationalist and an early scientific exponent of the Aryan race myth, and Rudolf Virchow (whose trenchant arguments against a Darwinism then still innocent of genetics are rather skimped). Haeckel became a champion of eugenics, revered in due course by the Nazis, and some of the leading German scientists travelled the terrible road from eugenics to an endorsement of the Final Solution.

In the $1930 \mathrm{~s}$ and $1940 \mathrm{~s}$, the political programme of human domestication was forever discredited by the Nazis. Its scientific basis had also been undermined by the new evolutionary synthesis of Mendelianism and Darwinism. Shipman captures the post-war mood in her account of Julian Huxley's virtuoso campaign at UNESCO (United Nations Educational, Scientific and Cultural Organization) against racist thinking. Before the war he had ridiculed the stereotype of the Aryan: " as blond as Hitler, as dolichocephalic as Rosenberg, as tall as Goebbels, as slender as Goering, and as manly as Streicher". Julian Huxley had played a distinguished part in the formulation of the evolutionary synthesis, and although once an advocate of eugenics and frankly antisemitic, he now insisted that "races" were social constructs rather than biological entities (phenotypical features being a poor guide to the constitution of the inner man, and migration and interbreeding in any case hopelessly confusing the genetic picture).

There was a similar reaction within US anthropology. Sherwood Washburn, Theodosius Dobzhansky and Ashley Montagu led the charge against the typological thinking in the name of the evolutionary synthesis. The scientific debates were engulfed by political emotions as the civil-rights movement gained momentum, and there were ugly confrontations. Shipman tells with sympathy the story of the humiliation of one of the old guard, the race typologist Carleton Coon. She dismisses the widespread belief that he knew very well what political capital would be made from his speculations, but she is less charitable to his opponents, imputing political motives for their rejection of race as a significant element in human biology.

Having illustrated the unending interplay of the science and politics of race, Shipman draws an unexpected moral: the frontier between science and politics must be more strictly policed. Scientists should press on with their studies without bothering about the vulgar abuses to which their research might lead. She quotes but dismisses rather too easily the view of an Afro-American intellectual that "there are types of research that shouldn't be done, and the grounds on which I argue are civility". We must, she tells us, continue to do research into human differences.

But there is no way to prevent public debate on any research that impinges on race, or on the biology of difference more generally. As she shows, even research proposals can become national political issues. Moreover, there is still little to suggest that this is a line of research that will yield important new insights. Shipman implies that there are significant differences between populations that may be explained by a more modern, more sophisticated, more nuanced theory of race, or perhaps by the discovery - at long last of genetically controlled differences in personality, or sexual disposition, or proclivities to violence or perhaps even rationality. So far, these associations remain highly speculative. (Oddly, she ignores human sociobiology, which has pursued this grail for 20 years, albeit without notable success.) Only one thing seems to have been established beyond any doubt, as her book makes very apparent. From the debates between the Darwinians and their opponents in the 1860 s to the clashes over The Bell Curve, it has proved impossible to insulate theories about race from their political implications.

Adam Kuper is in the School of Social Studies, Institute for Advanced Study, Olden Lane, Princeton, New Jersey 08540, USA.

\title{
Huxley goes to Hollywood
}

\section{W. F. Bynum}

Huxley: The Devil's Disciple. By Adrian Desmond. Michael Joseph: 1994. Pp. 475. $£ 20$.

HE would, wouldn't he? Adrian Desmond, fresh from the coauthored blockbuster study of Charles Darwin, has turned to T. H. Huxley as a natural sequel. The remarkable thing is that the companion piece has appeared so soon. Those who liked Darwin, which Desmond wrote with James Moore, need have no fear. Huxley is in the same mould. It has the same powerful style and the same penchant for florid language and colourful imagery. It is also based on a comparable mass of archival research, unobtrusively documented. Like Darwin, Huxley is a jolly good read.

In a brief prolegomenon, Desmond identifies the guiding principle underlying both of these highly imaginative biographies. "Huxley uses a 'ciné theory' of narration, with its historiography hidden, to conjure up a flesh-and-blood picture of T. H. Huxley", he tells us, citing as the technique's authority a forthcoming article by Moore. In practice, this means that the reader is invited to forget everything that has previously been written about Huxley and pretend to be there with him at home and abroad, to witness the development of the Devil's Disciple. Desmond's narrative rarely looks ahead, rarely pauses to take stock, never explicit-

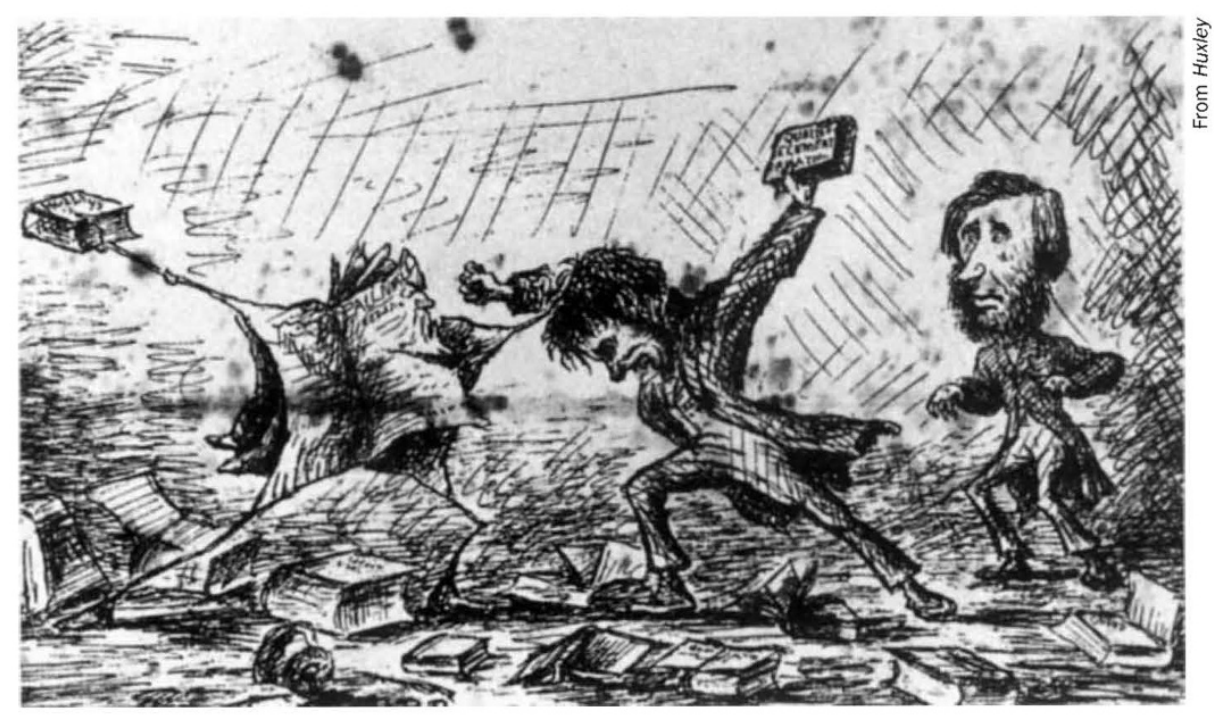

Huxley rages against the Pall Mall Gazette, as J. Tyndall looks on. 
ly considers what other scholars have made of this or that episode, confrontation or discovery. Desmond's camera is almost always just behind Huxley's shoulder.

Cynics might suggest that cine theory is suitable only for tabloid biographies and romantic novels (or films): that it is the dominant technique of the recent biographies of Nancy Reagan and the Princess of Wales. Nevertheless, the technique works here for Desmond, for two reasons. One is simply his integrity. He stays close to his sources so that almost every paragraph in the whole volume contains one or more quotations, mostly from Huxley's correspondence. These give his narrative the immediacy that the cine theory requires. Huxley had execrable handwriting but a wonderful way with words. Desmond deserves a prize merely for taking Huxley on.

The extent of the archival remains (more than 5,000 letters in the Huxley Archive at Imperial College, London) is the second reason why Desmond could write the kind of biography he has. It would be impossible to do the same for George Busk, W. B. Carpenter or some of Huxley's other close friends. It might even be difficult for Richard Owen, whose papers were carefully weeded by his grandson. Desmond, the silent cameraman, never offers us his reflections on gaps (deliberate or accidental) in the Huxley Archive.

Despite the fullness of his sources, Desmond occasionally slips into the novelist's mode, even in the very opening paragraph of the book:

The lanky 15-year-old sidled down fetid alleys, past gin palaces and dance halls. Sailors hung out of windows, the gaiety of their boozy whores belying the squalor around them. The boy's predatory looks and patched clothes seemed in keeping. But his black eyes betrayed a horror at the sights: ten crammed into a room, babies diseased from erupting cesspits, the uncoffined dead gnawed by rats. The scenes would scar him for life.

This is powerfully evocative, almost certainly poetically true and maybe even literally correct. We can never be sure. Here, as elsewhere, Desmond the cameraman becomes Desmond the director. $\mathrm{He}$ asks, therefore, for a lot of trust. It is amply rewarded. The flesh-and-blood Huxley who emerges from this book is eminently believable, more fascinating in his own right than he could ever be simply as Darwin's Bulldog. Indeed, in many ways, Huxley is a more appropriate character for Desmond's sensibilities than the rich, remote, neurotic Darwin. We are told on the second page (and subsequently reminded several times) that Huxley was born over a butcher's shop. He was a self-made man, surrounded by free-falling relatives, forced to scrimp and borrow his

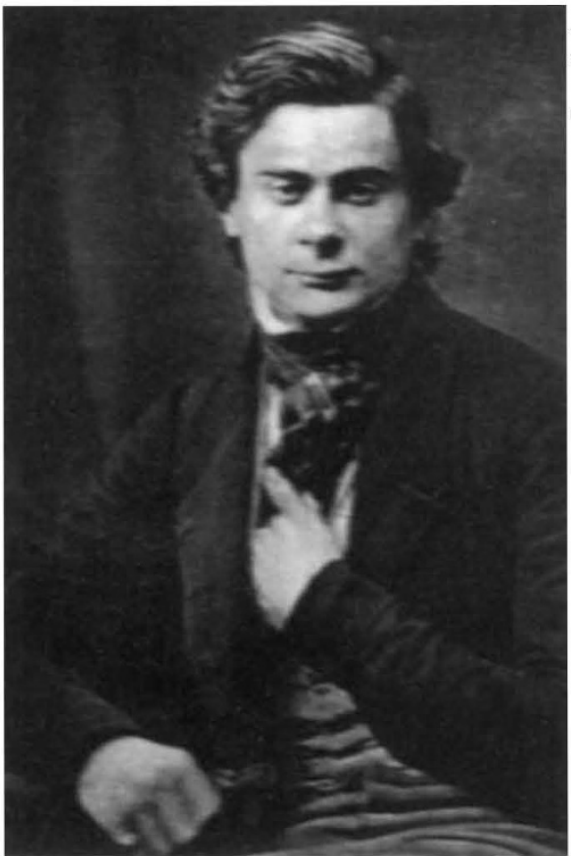

Black-eyed Tom in 1846.

way through medical school at Charing Cross Hospital, London, unable to afford the complete set of examinations that could have lead to a career as a consulting surgeon. Instead, he chose the even thornier path: to become a professional scientist. Unlike many upwardly mobile individuals (a recent British prime minister springs to mind), Huxley never turned mean, never ceased to be indignant that a rich country could permit so many of its citizens to remain poor.

There are many good things in Desmond's book. Two in particular stand out. The first is his reconstruction of Huxley's years as assistant surgeon on HMS Rattlesnake. Almost as long $(40,000$ miles, and two months short of four years) as Darwin's Beagle trek, this voyage was the making of Huxley. It committed him to science, established his reputation and taught him to love, even if his marriage had to wait another four years. No one has ever charted Huxley's experiences so fully, or shown how formative they were.

Desmond's second outstanding achievement is to document the seachange of public opinion between about 1855 and 1870 . The Origin of Species provided a turning point, of course, but looking through Huxley's rather than Darwin's eyes provides a broader vision. In those years, professional secular science was established in Britain. Huxley's generation came to maturity. He, John Tyndall, George Busk, Edward Franklin, Joseph Hooker, William Flower, John Lubbuck and others of like mind found themselves in positions of power within the British scientific establishment, and with friends in high places in government. Huxley's was not simply a fight Für Darwin; it was a battle on behalf of the social and intellectual value of scientific enquiry. The military metaphors were Huxley's.

Historians have often revelled in the irony that Darwin's Bulldog never really appreciated the explanatory power of natural selection, and took almost a decade even to value Darwin's ideas on genealogical taxonomy. Desmond deftly handles Huxley's relationship to Darwin by showing that, for Huxley, the stakes were higher than the contents of any one book, no matter how great.

In 1869 , Huxley was elected president of the British Association for the Advancement of Science. Desmond takes him to his 1870 presidential address and, then, without explanation, leaves him. There is not a single word on the last 25 years of his eventful life, nor any hint of a second volume. The camera simply runs out of film. We are thus deprived of the American tour, the continuing educational activities, the presidency of the Royal Society, the altercation with Prime Minister William Gladstone and the remarkable Romanes lecture. At least 1870 catches Huxley's intimate involvement with the foundation of a new weekly journal. "What a glorious title, Nature. It is more than cosmos. More than Universe". The words were not Huxley's, but they could have been.

W. F. Bynum is in the Wellcome Institute for the History of Medicine, 183 Euston Road, London NW1 2BE, UK.

\section{Sociological searchlights}

\section{John Ziman}

Handbook of Science and Technology Studies. Edited by Sheila Jasanoff, Gerald E. Markle, James C. Peterson and Trevor Pinch. SAGE: 1994. Pp. 820. \$85, $£ 65$.

IT was not until the 1960 s that people interested in studying science began to realize that it was, above all, a social institution. Turning away from philosophy towards sociology, they opened up a vast new field of research. The annual meetings of the Society for Social Studies of Science (' $4 S$ '), which was founded about 20 years ago, are now the marketplace for a bewildering variety of academic wares. In 1988 , the society set up a committee to prepare this comprehensive guide to their products. Here, in a pumpkin rather than a nutshell, is what STS - science and technology studies - is supposed to be about.

This fat volume is best read as a collection of 28 well informed local surveys of a 